Economica: Jurnal Ekonomi Islam - Volume 9, Nomor 1 (2018): 83 - 104

ISSN: 2085-9325 (print); 2541-4666 (online)

DOI: https://dx.doi.org/10.21580/economica.2018.9.1.2053

\title{
Model Inovasi Produk Perbankan Syariah di Indonesia
}

\author{
Hani Werdi Apriyanti \\ Universitas Islam Sultan Agung Semarang \\ email: hani.apriyanti@unissula.ac.id
}

\begin{abstract}
Sharia banking faces various challenges in order to reach market share both sharia banking and the other one. The sharia banking industry in Indonesia must take competitive advantage through product innovation. This research suggests conceptual model product innovation for sharia banking industry using the opportunity of global sharia economic development and the international trust in Indonesia. Product innovation for sharia banking can achieved by strengthening Sharia Banking Working Group, sharia compliance, financial stability, product innovation activity. This model expected to encourage market expansion both domestically and abroad. It's achieved by providing a variety of products that are closer and accepted by the community, with products that have a high social attachment (close to the society).
\end{abstract}

Keywords: Product Innovation; Sharia Banking Working Group; Sharia Compliance; Financial Stability; Product Innovation Activity.

Abstrak: Perbankan syariah saat ini dihadapkan pada persaingan yang ketat dalam meraih pangsa pasar, baik persaingan antara bank syariah dengan bank konvensional maupun antarsesama bank syariah. Oleh karena itu, perbankan syariah harus memiliki keunggulan kompetitif dengan melakukan inovasi produk. Penelitian ini mengusulkan model inovasi produk dengan memanfaatkan peluang pesatnya perkembangan ekonomi syariah global dan membaiknya kepercayaan dunia internasional terhadap ekonomi Indonesia dengan dukungan penguatan Working Group Perbankan Syariah (WGPS), pemenuhan ketentuan syariah (sharia compliance), pencapaian stabilitas keuangan, serta peningkatan dalam aktivitas inovasi produk. Model yang diusulkan diharapkan dapat mendorong perluasan pasar perbankan syariah baik di dalam negeri maupun luar negeri dengan menyediakan beragam produk yang lebih dekat dan diterima masyarakat. Perbankan syariah diharapkan melakukan inovasi produk yang memiliki kelekatan sosial tinggi (dekat, dapat diterima, serta sesuai dengan preferensi masyarakat).

Kata Kunci: Inovasi Produk Perbankan Syariah; WGPS; Stabilitas Keuangan; Aktivitas Inovasi.

Economica: Jurnal Ekonomi Islam - Volume 9, Nomor 1 (2018) 


\section{Pendahuluan}

Industri keuangan syariah di Indonesia mengalami perkembangan yang cukup baik (Utama and Handini 2017). Perkembangan industri perbankan syariah ini dipengaruhi oleh berbagai faktor, yaitu faktor internal seperti Sumber Daya Manusia (SDM), pendanaan, good corporate governance, serta faktor eksternal seperti pertumbuhan ekonomi dan insfrastuktur kelembagaan syariah nasional maupun internasional. Salah satu infrastruktur kelembagaan syariah pada tingkat nasional yang mendorong pertumbuhan bank syariah adalah Otoritas Jasa Keuangan (OJK). OJK terus mendorong dan mengarahkan bank syariah menuju industri perbankan syariah yang sehat, berkelanjutan, dan berkontribusi positif dalam mendukung pembangunan ekonomi yang berkualitas.

Perkembangan yang cukup baik dalam industri keuangan syariah memberikan dampak yang positif terhadap ekonomi masyarakat. Industri Perbankan syariah dapat memberikan kontribusi besar dalam melakukan transformasi perekonomian pada aktivitas ekonomi yang produktif, bernilai tambah dan inklusif. Dengan progres perkembangannya yang impresif, yang mencapai rata-rata pertumbuhan aset lebih dari $65 \%$ pertahun dalam lima tahun terakhir, peran industri perbankan syariah dalam mendukung perekonomian nasional menjadi semakin signifikan. Peran strategis ini terus didorong dengan beberapa kebijakan yang telah ditetapkan oleh lembaga yang berwenang. Hal ini terbukti bahwa salah satu prioritas kebijakan OJK pada tahun 2016 sektor perbankan, adalah peningkatan kontribusi perbankan syariah bagi perkonomian nasional (Otoritas Jasa Keuangan 2015a). Agenda-agenda penting dalam rangka pengembangan perbankan syariah di Indonesia terus dilakukan secara bersinergi antara pelaku industri dengan pemerintah melalui Komite Keuangan Syariah Nasional (KNKS), OJK dan kerjasama bank-bank syariah di Indonesia.

Setelah diberlakukannya Masyarakat Ekonomi Asean (MEA) pada tahun 2015, persaingan dalam industri keuangan syariah semakin tinggi. Perbankan 
syariah dituntut untuk memiliki keunggulan kompetitif yang berbeda dengan industri perbankan konvensional, sehingga dapat menjadi pilihan masyarakat. Di era financial digital, industri perbankan syariah dapat memanfaatkan peluang agar mampu tumbuh menjadi industri perbankan syariah yang kontributif dan kuat, baik di dalam maupun di luar negeri. Industri perbankan syariah dapat memanfaatkan berbagai peluang, yaitu dengan menyediakan inovasi produk untuk menyediakan beragam pilihan dan memperluas jangkauan pada masyarakat (Ulum 2014).

Perbankan syariah dihadapkan pada permasalahan jangkauan bank syariah yang masih terbatas, yaitu 55\% kabupaten atau kota di Indonesia serta permasalahan inovasi produk. Inovasi Produk perbankan syariah belum mampu menjawab kebutuhan pasar dan berdaya saing tinggi. Permasalahan lain dalam inovasi produk adalah belum melalui proses inovasi produk dengan pemanfaatan teknologi informasi dan telekomunikasi.

Oleh karena itu perbankan syariah dituntut untuk dapat menerapkan model strategi yang tepat guna untuk dapat memperluas jangkauan baik pasar domestik maupun luar negeri (Gunawan, Mukoffi, and Handayanto 2017). Di samping itu, juga dituntut untuk dapat menerapkan inovasi pada penghimpunan dana yang berbiaya murah dengan tingkat likuiditas yang rendah (Utama and Handini 2017). Hasil Penelitian Gunawan, dkk (Gunawan, Mukoffi, and Handayanto 2017) menunjukkan bahwa produk perbankan syariah tidak variatif. Produk-produk bank syariah kurang bervariasi, hanya terbatas pada produk tabungan, deposito, giro, pembiayaan murabahah, dan syirkah (Indriati 2011). Dari segi skema pembiayaan maupun jumlah, produkproduk perbankan syariah masih sangat terbatas.

Oleh karena itu, inovasi produk perbankan syariah masih menjadi salah satu isu strategis dalam roadmap perbankan syariah 2015-2019 yang harus segera diselesaikan. Berbagai hal yang terkait dengan rendahnya variasi produk perbankan syariah adalah modal yang belum memadai, skala industri yang kecil, efisiensi yang rendah, biaya dana yang mahal, kuantitas dan 
Hani Werdi Apriyanti

kualitas SDM yang belum memadai, serta teknologi informasi yang belum mendukung (Otoritas Jasa Keuangan 2017). Hal ini juga disampaikan oleh Harahap (Harahap 2017) bahwa perbankan syariah masih dihadapkan pada kendala keterbatasan modal, sumber dana, SDM, serta TI yang belum memadai.

Penelitian ini bertujuan untuk mengembangkan model konseptual dalam inovasi produk perbankan syariah di Indonesia. Penelitian ini berusaha mengusulkan beberapa variabel yang perlu dikembangkan dan diterapkan oleh perbankan syariah dalam inovasi produk, yaitu dengan peningkatan Jaringan Perbankan Syariah (Working Group Perbankan Syariah/ WGPS), pemenuhan ketentuan syariah (sharia compliance), pencapaian stabilitas keuangan, serta perbaikan dalam aktivitas inovasi.

\section{Telaah Pustaka}

\section{Perbankan Syariah}

Perbankan syariah adalah segala sesuatu yang menyangkut tentang bank syariah dan unit usaha syariah, mencakup kelembagaan kegiatan usaha, serta cara dan proses dalam melaksanakan kegiatan usahanya (Undang-Undang Nomor 21 Tahun 2008 tentang Perbankan Syariah). Bank syariah adalah bank yang menjalankan kegiatan usahanya berdasarkan prinsip syariah. Prinsip syariah adalah prinsip hukum Islam dalam kegiatan perbankan berdasarkan fatwa yang dikeluarkan oleh lembaga yang memiliki kewenangan dalam penetapan fatwa di bidang syariah (Otoritas Jasa Keuangan 2016). Industri perbankan syariah memiliki karakteristik umum yang melekat pada industri perbankan, yaitu industri yang padat regulasi, dan industri yang berdasarkan pada kepercayaan.

Sistem perbankan syariah di Indonesia dilaksanakan dengan sistem prinsip bagi hasil, mengedepankan nilai kebersamaan, ukhuwah, dan penghindaran unsur spekulatif dalam setiap transaksinya (Alamsyah 2012). Dalam menjalankan kegiatan usaha bank syariah berdasarkan prinsip syariah, 
demokrasi ekonomi, dan prinsip kehati-hatian (Otoritas Jasa Keuangan 2017). Kegiatan usaha yang dijalankan oleh bank syariah tidak boleh mengandung unsur riba, maisir, gharar, haram, dan zalim (sesuai prinsip syariah), harus mengandung nilai keadilan, kebersamaan, pemerataan serta kemanfaatan (demokrasi ekonomi).

Sebagai lembaga keuangan syariah, bank syariah memiliki peran dan fungsi ganda yang berbeda dengan bank konvensional. Bank syariah melakukan aktifitas yang berorientasi laba serta orientasi sosial. Bank syariah berperan sebagai financial intermediary dalam bentuk pembiayaan transaksi jual beli (debt financing), pembiayaan usaha (profit lost sharing), pembiayaan berbasis fee/ujrah, serta memiliki fungsi sosial sebagai penampung dana zakat dan pinjaman kebajikan/dana talangan (qard dan qarḍ al-ḥasan).

Dengan fungsi yang begitu kompleks, maka bank syariah dihadapkan pada berbagai macam tantangan. Di tengah persaingan dan tantangan yang dihadapai, industri perbankan syariah dapat tumbuh, dengan pertumbuhan aset terbesar kesembilan di dunia dengan aset 35,6 milyar USD pada tahun 2013 (Otoritas Jasa Keuangan 2017). Agar dapat berkembang dengan baik, maka bank syariah harus memiliki platform bagi pengembangan dan inovasi produk yang semakin beragam. Berbagai macam upaya harus dilakukan oleh perbankan syariah sebagai pelaku industri dalam rangka memperluas jangkauan kepada masyarakat dengan melakukan tambahan variasi produk mengikuti regulasi OJK serta fatwa Dewan Syariah Nasional MUI.

\section{Produk dan Jasa Perbankan Syariah}

Bank syariah melakukan kegiatan usaha yaitu penghimpunan dana dari masyarakat, penyaluran dana kepada masyarakat, dan melakukan berbagai macam jasa sesuai dengan prinsip syariah. Setiap produk dan jasa yang dikeluarkan oleh bank syariah harus sesuai dengan POJK No. 24/POJK.03/2015 tentang produk dan aktivitas bank syariah, SEOJK No.

Economica: Jurnal Ekonomi Islam - Volume 9, Nomor 1 (2018) 
Hani Werdi Apriyanti

36/SEOJK.03/2015 tentang produk dan aktivitas BUS dan UUS, serta SEOJK No. 37/SEOJK.03/2015 tentang produk dan aktivitas BPRS.

Bank syariah menjalankan operasional kegiatan usahanya dengan melakukan penghimpunan dana (produk giro syariah, tabungan syariah, deposito syariah), penyaluran daana (pembiayaan investasi syariah, pembiayaan modal kerja syariah, pembiayaan konsumtif syariah), dan melakukan jasa gadai emas, pembiayaan ekspor impor non L/C. Tabel 1 menjelaskan rangkuman produk dan jasa perbankan syariah sesuai dengan kegiatan usaha perbankan syariah.

Tabel 1. Produk dan Jasa Perbankan Syariah di Indonesia

\begin{tabular}{|c|c|c|}
\hline Kegiatan Usaha & Produk & Akad yang Digunakan \\
\hline Penghimpunan & 1. Giro Syariah & Wadīah/lainnya \\
\hline Dana & $\begin{array}{l}\text { 2. Tabungan Syariah } \\
\text { 3. Deposito Syariah }\end{array}$ & Wadī'ah/Muḍārabah \\
\hline Penyaluran Dana & $\begin{array}{l}\text { 1. Pembiayaan Investasi Syariah } \\
\text { 2. Pembiayaan Modal Kerja Syariah } \\
\text { 3. Pembiayaan Konsumtif Syariah }\end{array}$ & $\begin{array}{l}\text { Murābaḥah } \\
\text { Salam, Salam Paralel } \\
\text { Istișnā', Istișnā' Paralel } \\
\text { ljārah } \\
\text { Muḍārabah } \\
\text { Mushārakah }\end{array}$ \\
\hline Melakukan Jasa & $\begin{array}{l}\text { 1. Gadai Emas } \\
\text { 2. Pembiayaan Ekspor Impor non LC } \\
\text { 3. L/C Impor } \\
\text { 4. L/C Ekspor } \\
\text { 5. Surat Kredit Berdokumen Dalam Negeri } \\
\text { 6. Bank garansi } \\
\text { 7. Penukaran Valuta Asing } \\
\text { 8. Safe Deposit Box } \\
\text { 9. Traveler Cheque } \\
\text { 10. Agen Penjualan reksadana, Asuransi dan } \\
\text { 11. Transfer } \\
\text { 12. Credit Card, Charge Card } \\
\text { 13. Payrol }\end{array}$ & $\begin{array}{l}\text { Wakālah } \\
\text { Kafālah } \\
\text { Hawālah } \\
\text { Șarf }\end{array}$ \\
\hline
\end{tabular}

Sumber : OJK (2017), Data Penelitian yang diolah 


\section{Inovasi Produk Perbankan Syariah}

Dalam menjalankan kegiatan usahanya, perbankan syariah berlandaskan pada prinsip bagi hasil (Masulah 2014). Karakteristik yang ada dalam produk perbankan syariah ini, memberikan alternatif sistem perbankan yang saling menguntungkan bagi kedua belah pihak, yaitu masyarakat dan perbankan, serta mengedepankan aspek keadilan dalam bertransaksi, investasi yang beretika, nilai-nilai kebersamaan dan ukhuwah dalam berproduksi, dan menghindari kegiatan spekulatif dalam bertransaksi (Indriati 2011).

Produk perbankan syariah, saat ini terus dikembangkan, yaitu dengan menyediakan beragam produk serta layanan jasa perbankan yang beragam dengan skema keuangan yang lebih bervariatif. Upaya ini merupakan upaya yang disebut sebagai inovasi dalam produk perbankan syariah. Inovasi produk perbankan syariah ini merupakan pilar utama dalam pengembangan perbankan syariah (Himatansi 2009). Upaya ini dapat menjadikan perbankan syariah sebagai alternatif sistem perbankan yang kredibel dan dapat dinikmati oleh seluruh golongan masyarakat Indonesia tanpa terkecuali. Inovasi produk yang sejalan dengan pemenuhan kebutuhan masyarakat dapat melahirkan produk bank yang variatif (Indriati 2011). Inovasi produk yang dilakukan perbankan syariah dapat berupa produk yang akan dikemas kembali (repackage) maupun produk baru (new product).

Kian (Kian 2016) menyatakan bahwa pengembangan inovasi produk perbankan syariah harus sesuai dengan standar internasional dan merujuk pada rumusan strategi pengembangan perbankan syariah. Keselarasan ini terutama diterapkan dalam perancangan instrumen produk yang dikembangkan. Selain itu pengembangan produk juga harus disesuaikan dengan kualitas produk, keandalan SDM, serta jangkauan jaringan kantor perbankan syariah.

Economica: Jurnal Ekonomi Islam - Volume 9, Nomor 1 (2018) 
Hani Werdi Apriyanti

Bank syariah dapat mengembangkan produk yang sudah ada di kodifikasi produk perbankan syariah yang sudah ditetapkan. Pengembangan produk sesuai dengan kodifikasi akan mempermudah perbankan syariah dalam pengembangan produk baru, karena perbankan dapat lebih fokus pada pengembangan instrumen produk sesuai kodifikasi yang ditetapkan. Hal ini juga dapat dilakukan dengan mudah, karena model pengembangan ini tidak diperlukan perijinan khusus dari OJK, hanya diharuskan pelaporan realisasi kepada OJK. Jika bank syariah akan mengembangkan produk, tetapi belum ada di dalam kodifikasi, maka pengembangan produk tersebut harus memperoleh ijin dari OJK.

\section{Landasan Syariah Inovasi produk}

Dalam melakukan inovasi produk, perbankan syariah dapat menggunakan kaidah fikih dalam syariah, yaitu bahwa hukum (muamalah) dapat berubah karena perubahan zaman, tempat, keadaan, adat, dan niat. Kaidah fikih ini dapat dijadikan landasan oleh bank syariah dalam melakukan inovasi produk. Berdasarkan kaidah fikih tersebut, hukum muamalah yang diterapkan dalam produk perbankan syariah dapat berubah mengikuti perkembangan dan kebutuhan zaman, tempat serta kondisi kontemporer. Pemenuhan akan preferensi masyarakat terhadap produk perbankan yang disesuaikan dengan kebutuhan zaman, tempat dan kondisi kontemporer juga harus berpedoman pada fatwa MUI yang telah ditetapkan oleh Dewan Syariah Nasional (DSN) MUI.

Dalam melakukan pengembangan produk, bank syariah harus tetap patuh pada prinsip syariah. Dalam rangka memenuhi variasi produk, maka bank syariah dapat menerbitkan produk baru yang sudah ada dalam kodifikasi produk perbankan syariah, maupun produk yang belum ada dalam kodifikasi. Setiap produk yang diterbitkan bank syariah harus memenuhi ketentuan berkaitan dengan perizinan produk, sesuai dengan prinsip syariah, 
dan sesuai peraturan perundang-undangan yang berlaku. Ada dua perlakuan berbeda untuk dua jenis produk tersebut, yaitu:

1. Untuk produk yang sudah masuk dalam kodifikasi produk perbankan syariah, maka ketika bank syariah menerbitkan produk baru tersebut tidak diperlukan persetujuan OJK. Bank hanya wajib melakukan pelaporan realisasi pada tujuh hari kerja setelah produk baru tersebut diterbitkan.

2. Bank harus mengajukan persetujuan selama 30 hari sebelum produk baru diterbitkan kepada OJK dan juga wajib melaporkan laporan realisasi pada 7 hari kerja.

\section{Metode Penelitian}

Penelitian ini bertujuan mengembangkan model konseptual strategi inovasi produk pada perbankan syariah dengan memanfaatkan peluang pesatnya perkembangan ekonomi syariah global dan membaiknya kepercayaan dunia internasional terhadap ekonomi Indonesia, dukungan penguatan Jaringan Perbankan Syariah (WGPS), dana (stabilitas keuangan), serta aktivitas dalam proses inovasi produk. Penelitian ini didasarkan pada data sekunder yang diperoleh dari buku, booklet, Undang-undang, jurnal, majalah dan internet. Kerangka kerja konseptual dikembangkan untuk menggambarkan masing masing dimensi yang dapat memperkuat inovasi produk perbankan syariah.

\section{Hasil dan Pembahasan}

\section{Kerangka Konseptual}

Arah pengembangan perbankan nasional sesuai OJK bersifat komprehensif dan terintegrasi dengan penyusunan arah pengembangan pasar modal dan industri keuangan nonbank. Arah pengembangan perbankan syariah dalam jangka menengah adalah pengembangan produk dan layanan yang berkualitas, inovatif, berbeda, dan lebih unggul (distinct) dari produk 
perbankan konvensional, dan perluasan jaringan yang luas agar mampu memenuhi kebutuhan masyarakat akan jasa keuangan syariah (Otoritas Jasa Keuangan 2016). Berdasarkan Roadmap Perbankan Syariah Indonesia 20152019, visi pengembangan perbankan syariah nasional adalah mewujudkan perbankan syariah yang berkontribusi signifikan bagi pertumbuhan ekonomi berkelanjutan, pemerataan pembangunan, dan stabilitas sistem keuangan serta berdaya saing tinggi (Otoritas Jasa Keuangan 2015b).

Kunci pengembangan perbankan syariah adalah dengan inovasi produk. Inovasi produk menjadi isu strategis dan menjadi tanggung jawab bersama antara bank sebagai pelaku usaha, pemerintah melalui OJK sebagai regulator, dan Majelis Ulama Indonesia (MUI). Untuk mencapai hal tersebut, kunci dalam melakukan inovasi produk adalah dengan mencapai stabilitas keuangan. Dengan adanya tuntutan pertumbuhan serta variasi produk yang semakin banyak, maka dibutuhkan pengelolaan risiko (manajemen risiko) yang lebih baik agar tercipta stabilitas sistem keuangan. Manajemen risiko sangat dibutuhkan oleh perbankan syariah, mengingat keunikan bank syariah dalam prinsip dan operasionalnya yang sangat berbeda dengan bank konvensional. Inovasi produk harus memerhatikan faktor manajemen risiko untuk meminimalkan risiko kerugian (Danila 2014). Dalam rangka mewujudkan stabilitas keuangan, diperlukan koordinasi yang baik antara OJK dan pelaku usaha berkaitan dengan implementasi kebijakan yang tepat, sehingga stabilitas keuangan dapat tercapai. Dengan stabilitas keuangan yang baik, maka strategi inovasi produk bank dapat dilaksanakn oleh bank syariah.

Dalam melakukan pengembangan produk bank syariah, bank harus memanfaatkan teknologi Informasi sebagai sarana dalam menyampaikan nilai (value) kepada masyarakat melalui produk baru. Hal lain yang perlu dilakukan adalah meningkatkan peran WGPS untuk meningkatkan kerjasama dalam berbagai macam kegiatan pengembangan produk perbankan syariah. Pengembangan produk yang dilakukan, harus selaras dengan fatwa DSN-MUI. Fatwa tersebut dapat dijadikan landasan dalam setiap upaya menciptakan 
variasi produk. Pemenuhan kepatuhan terhadap ketentuan syariah ini harus tetap dilakukan, meskipun produkyang disediakan sangat beragam dan dekat dengan masyarakat (M. Hafidz MS. 2015). Hal ini berarti seharusnya tidak ada penyimpangan pada tataran praktis yang terjadi di perbankan syariah dalam setiap skema pembiayaan yang diberikan kepada masyarakat. Pemenuhan ini seharusnya dilakukan oleh Badan Pengawas Syariah (DPS) sebagai badan pengawas serta OJK sebagai regulator yang mengeluarkan kebijakan sekaligus sebagai pengawas perbankan syariah yang ada di Indonesia.

Gambar 1. Kerangka Konseptual Model Penguatan Inovasi Produk Perbankan Syariah

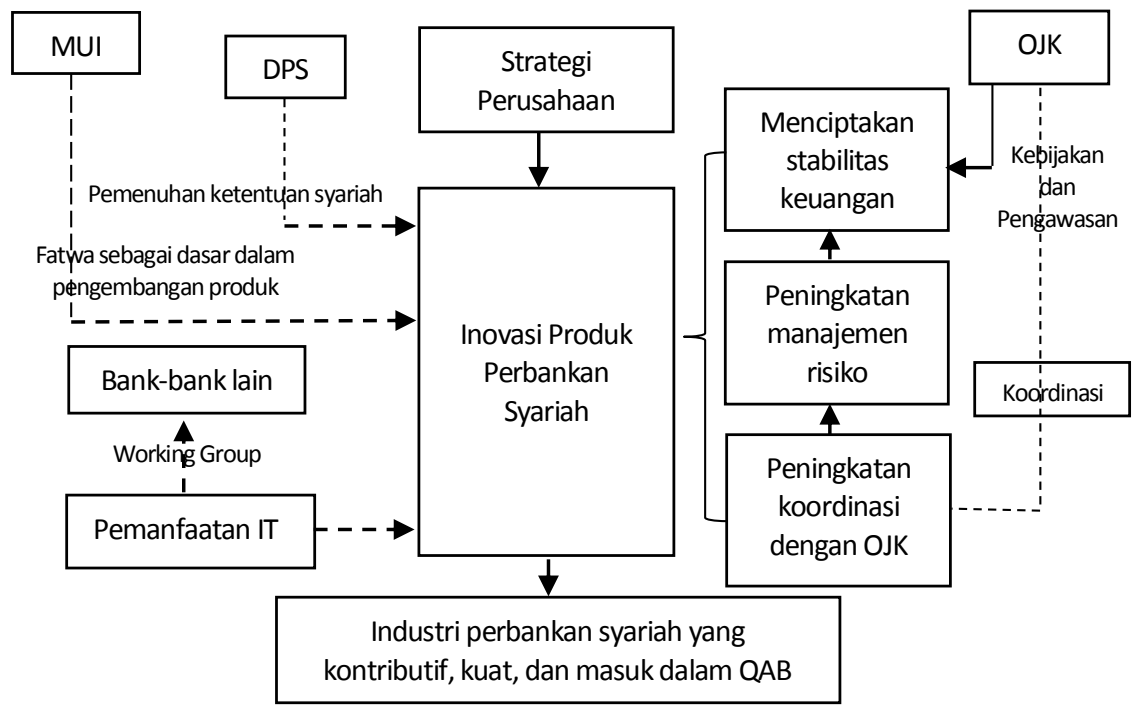

\section{Strategi Inovasi Produk Bank Syariah di Indonesia}

Di era financial digital, perbankan syariah harus menciptakan competitive advantage dengan memanfaatkan teknologi dalam transaksi e-commerce. Beragam produk yang dekat dengan masyarakat harus diciptakan dengan cara baru, yaitu memberikan pengalaman kepada masyarakat untuk lebih mengenal produk, memberikan kesan dan pengalaman baru dalam bertransaksi yang sesuai dengan prinsip syariah. Pengalaman yang berkesan

Economica: Jurnal Ekonomi Islam - Volume 9, Nomor 1 (2018) 
dalam bertransaksi muamalah disesuaikan dengan perkembangan teknologi dengan pemanfaatan teknologi dalam setiap transaksi muamalah.

\section{Jaringan Perbankan Syariah (Working Group Perbankan Syariah)}

Perbankan syariah harus mulai memanfaatkan bonus demografi dan terjun dalam international banking, mengikuti bank syariah pertama di Indonesia, yaitu Bank Muamalat. Selain fokus pada penghimpunan dana pada sektor publik, lembaga pemerintah dan swasta, bank harus menggerakkan program penghimpunan dana dalam valuta asing melalui pemberdayaan kantor cabang di luar negeri. Selain itu, bank syariah dapat memanfaatkan Working Group Perbankan Syariah (WGPS) pada aktivitas financing melalui program channeling melalui perusahaan afiliasi maupun nonafiliasi. Bank Umum Syariah (BUS) dapat menggandeng sejumlah Bank Pembiayaan Rakyat Syariah (BPRS). Kesadaran akan konsep saling tolong menolong dalam kebaikan serta konsep beramal jama’i (bekerja sama) atau bersinergi antarbank syariah seharusnya mulai ditingkatkan. Bank syariah dalam sebuah kesatuan WGPS dapat melakukan sinergi produk bersama. Dengan adanya produk bersama, maka masyarakat akan lebih mengenalnya sebagai gerakan bersama yang akan menjadi lebih menarik, dan dapat menjadi animo besar bagi perkembangan perbankan syariah.

Dalam rangka inovasi produk dengan menyediakan beragam produk yang dekat dengan masyarakat, bank syariah harus meningkatkan jaringan. Hal ini dilakukan untuk memberikan pelayanan yang lebih baik, yaitu dengan transaksi muamalah yang terintegrasi dengan bisnis lainya melalui pemanfaatan teknologi dan media yang ada. Luasnya jaringan dengan bisnis lainya akan memudahkan bank menyediakan layanan dan produk yang dekat dengan masyarakat. Kedekatan produk bank syariah dapat diupayakan melalui channel distribusi bank, dengan kantor layanan atau cabang serta melalui website (salah satu pemanfaatan teknologi). Selain itu, bank syariah di Indonesia dapat membangun hubungan kerjasama dengan lembaga 
keuangan internasional dalam rangka pengembangan produk yang bervariasi dan menarik. Hal ini dilakukan sebagai proses pembelajaran dan mengambil best practice dari negara-negara yang telah mengembangkan perbankan syariah. Dengan meningkatkan peran WGPS, maka tanggung jawab besar mendorong masyarakat menuju halal lifestyle banking akan terwujud.

\section{Pemenuhan Ketentuan Syariah}

Kepatuhan terhadap ketentuan syariah adalah pemenuhan seluruh prinsip syariah dalam seluruh aktivitas yang dilakukan oleh bank syariah (Waluyo 2016). Hal ini berarti dalam aktivitas inovasi produk, bank syariah juga harus taat terhadap prinsip syariah. Aspek kepatuhan atau pemenuhan terhadap ketentuan syariah bagi perbankan syariah merupakan hal yang penting, karena dapat digunakan sebagai alat dalam mitigasi risiko, serta pencegahan kecurangan (fraud) (Kian 2016). Kepatuhan terhadap ketentuan syariah merupakan bagian dari tindakan pencegahan atas risiko, serta memastikan kebijakan, ketentuan, sistem, prosedur, dan kegiatan usaha bank syariah agar sesuai dengan standar syariah dan syariah governance. Begitu juga dalam pengembangan produk, perbankan syariah harus mengacu pada standar syariah, syariah governance, dan standar internasional. Upaya pengembangan produk tidak boleh menzalimi masyarakat, dan harus memerhatikan kesesuaian akad produk yang dikembangkan dengan standar syariah.

Dalam rangka memenuhi, memastikan, dan menjamin ketaatan pada ketentuan syariah, bank memiliki dan menggunakan Dewan Pengawas Syariah (DPS) untuk memastikan bahwa setiap transaksi telah sesuai dengan ketentuan syariah. Selain itu, untuk mendukung inovasi produk, maka bank harus mengembangkan kebijakan dan aturan yang fleksibel dalam rangka inovasi produk. Setiap kebijakan yang dikembangkan selalu dalam pengawasan Dewan Pengawas Syariah (DPS) untuk menjamin ketaatan terhadap syariah.

Economica: Jurnal Ekonomi Islam - Volume 9, Nomor 1 (2018) http://journal.walisongo.ac.id/index.php/economica 
Akan tetapi, peran DPS dalam mengawasi operasional bank syariah masih terbatas, sehingga seringkali terjadi permasalahan dalam pemenuhan kepatuhan syariah, baik berupa penurunan kualitas kepatuhan sampai pada penyimpangan terhadap ketentuan syariah (Kian 2016). Oleh karena itu, pemenuhan terhadap ketentuan syariah perlu terus ditingkatkan, melalui proses protektif (dengan melakukan analisis terhadap berbagai bidang yang terkait, pemeriksaan, serta pengawasan oleh DPS maupun lembaga terkait), konstruktif (melalui ketepatan dalam penggunaan sumber daya), serta konsultatif (pemberian rekomendasi bagi perbankan syariah) (Kian 2016).

Upaya peningkatan dalam tingkat ketaatan bank syariah dalam memenuhi standar syariah serta syariah governance dapat dilakukan dengan melakukan sinergi antara bank sebagai pelaku bisnis, DPS sebagai pengawas syariah, serta OJK yang memiliki tiga fungsi sekaligus; perlindungan, asistensi dalam pembangunan perbankan syariah maupun fungsi konsultatif yang berkaitan dengan perbaikan bank syariah.

\section{Stabilitas Keuangan}

Aspek pemenuhan terhadap ketentuan syariah dapat dijadikan sebagai alat untuk mencegah berbagai macam kecurangan keuangan yang dapat dilakukan oleh pegawai, manajemen, maupun pemegang saham, serta alat untuk memitigasi risiko terutama berkaitan dengan risiko kepercayaan (trust) yang dapat berpengaruh terhadap stabilitas bank syariah, terutama stabilitas keuangan (Kian 2016). Kegagalan dalam pemenuhan standar syariah serta syariah governance akan berdampak pada menurunnya kepercayaan masyarakat terhadap perbankan syariah, sehingga dapat mengganggu proses dalam perolehan market share.

Oleh karena itu, bank syariah harus secara bersama memenuhi ketentuan tersebut, sehingga tidak mengganggu stabilitas keuangan. Stabilitas keuangan mutlak harus terpenuhi bagi perbankan syariah agar dapat mengembangkan inovasi produk. Bank syariah harus memiliki sumber 
pendanaan yang cukup untuk melakukan inovasi produk. Aktivitas dalam inovasi produk membutuhkan biaya dana yang cukup besar. Hal ini disebabkan oleh adanya kebutuhan inftrastruktur yang mahal dalam memenuhi harapan masyarakat yaitu produk yang dapat digunakan dengan mudah dan berbasis teknologi.

Stabilitas keuangan dapat diperoleh melalui proses manajemen risiko yang tepat, dan adanya perencanaan melalui anggaran yang fleksibel. Bank syariah harus siap menganggarkan beberapa pos biaya yang masuk dalam investasi jangka panjang yang akan mendorong perolehan return jangka panjang, seperti biaya penelitian dan pengembangan produk perbankan syariah. Kesiapan ini dibuktikan dari sikap manajemen yang bersedia untuk menunda pendapatan jangka pendek dengan mengalokasikan biaya (cost) untuk pengeluaran investasi jangka panjang.

Selain itu, perlu adanya koordinasi yang baik antara bank syariah dengan berbagai pihak yang terkait dengan memanfaatkan jaringan melalui WGPS dalam pemenuhan tujuan bank syariah, baik dalam hal pengembangan jaringan, pengenalan produk baru, maupun pemenuhan terhadap kebutuhan modal yang berasal dari pihak luar. Dengan mitigasi risiko yang tepat, penganggaran yang tepat, serta pemanfaatan WGPS sesuai dengan tujuan berdasarkan visi misi bank syariah, akan dapat memperkuat stablitas keuangan bank syariah dan mendukung inovasi produk perbankan syariah.

\section{Aktivitas dalam Inovasi Produk}

Aktivitas yang dilakukan oleh perusahaan dalam inovasi produk adalah bagian dari upaya bank syariah dalam memenuhi harapan dan preferensi masyarakat terhadap layanan dan produk bank syariah. Masyarakat memiliki kecenderungan memilih produk baru dengan kecepatan dan kemudahan bertransaksi (Al Fitri 2014). Oleh karena itu, bank syariah berusaha memenuhi harapan masyarakat dengan melakukan berbagai inovasi,

Economica: Jurnal Ekonomi Islam - Volume 9, Nomor 1 (2018) 
Hani Werdi Apriyanti

sehingga ketertarikan masyarakat terhadap produk bank syariah semakin besar.

Inovasi produk yang dilakukan untuk memenuhi kebutuhan pasar harus dilakukan berdasarkan pada survey pasar sesuai segmentasi, target serta posisi perusahaan (Hudaya 2011). Hal ini dilakukan untuk mendapatkan informasi yang valid tentang skema produk yang diinginkan dan dibutuhkan oleh masyarakat. Ini seharusnya dilakukan oleh bank syariah, sehingga inovasi yang dikembangkan selalu berdasar pada kebutuhan masyarakat, dengan harapan kebutuhan masyarakat akan terpenuhi. Hal lain yang dapat dilakukan adalah dengan melakukan pengamatan terhadap perilaku masyarakat. Aktivitas ini membutuhkan SDM yang handal dan waktu yang cukup panjang.

Aktivitas inovasi produk dapat dilakukan dengan melakukan pengembangan dan penciptaan produk baru, pengembangan produk lama, dan pengembangan model terhadap produk lama. Selain itu, inovasi produk dapat dilakukan melalui pemanfaatan akad, baik yang sudah masuk dalam kodifikasi maupun yang belum masuk dalam kodifikasi produk perbankan syariah. Beberapa akad yang telah masuk dalam kodifikasi dan merupakan pengembangan dari akad yang sudah ada, yaitu Musyarakah Mutanaqishah (MMQ) yang merupakan pengembangan dari produk berbasis akad musyarakah. Aplikasi dari akad ini yang sangat dibutuhkan oleh masyarakat adalah produk Kredit Pemilikan Rumah (KPR) dan Kredit Kendaraan Bermotor (KKB). Dengan pemanfaatan akad tersebut, masyarakat dapat memenuhi kebutuhan kepemilikan rumah dengan tetap mematuhi aturan syariah.

Akad lain yang dapat dikembangkan adalah syirkah kontemporer dan Ijarah Muntahiyah Bittamlik (IMBT), yaitu akad sewa menyewa yang disertai dengan opsi pemindahan hak milik atas benda yang disewa kepada penyewa setelah selesai masa sewa. Produk dengan akad tersebut, dapat memenuhi kebutuhan masyarakat terhadap kepemilikan benda tertentu. Selain itu, 
skema produk lainya yang saat ini sedang dikembangkan oleh perbankan syariah, yaitu mekanisme penyaluran dana, dengan rahn (gadai), dan șarfatau akad penukaran valuta asing. Tema-tema lain yang dapat dikembangkan dalam inovasi produk adalah sukuk serta hedging and liquidity management in islamic finance (Kian 2016).

Dengan berbagai macam pengembangan produk tersebut masyarakat akan terdorong untuk dapat memiliki gaya hidup halal lifestyle banking. Hal ini memungkinkan pemenuhan gaya hidup tersebut menjadi lebih mudah bagi masyarakat karena beragam pilihan dan kemudahan yang diberikan oleh perbankan syariah.

Tabel 1. Definisi Operasional dan Implikasi Praktis

\begin{tabular}{|c|c|c|c|}
\hline Variabel & Definisi & Dimensi & Implikasi \\
\hline $\begin{array}{l}\text { Working } \\
\text { Groups } \\
\text { Perbankan } \\
\text { Syariah } \\
\text { (WGPS) }\end{array}$ & $\begin{array}{l}\text { Sebuah kesatuan } \\
\text { dalam jaringan } \\
\text { kantor baik dalam } \\
\text { satu bank (berupa } \\
\text { channel distribusi, } \\
\text { atau kantor } \\
\text { cabang) maupun } \\
\text { antar perbankan } \\
\text { syariah, baik di } \\
\text { dalam maupun luar } \\
\text { negeri, serta } \\
\text { lembaga keuangan } \\
\text { internasional }\end{array}$ & $\begin{array}{l}\text { Social } \\
\text { networking }\end{array}$ & $\begin{array}{l}\text { 1. Pemenuhan jaringan } \\
\text { informasi, komunikasi dan } \\
\text { teknologi yang memadai } \\
\text { 2. Adanya channel distribusi } \\
\text { bank dan kantor cabang } \\
\text { 1. Bank tergabung dalam } \\
\text { Working Groups Perbankan } \\
\text { Syariah (WGPS) tertentu } \\
\text { 2. Bank terlibat dalam sinergi } \\
\text { produk bersama melalui } \\
\text { WGPS. } \\
\text { 3. Adanya program channeling } \\
\text { dalam aktivitas financing } \\
\text { melalui perusahaan afiliasi } \\
\text { maupun nonafiliasi } \\
\text { 4. Jaringan yang ada mendukung } \\
\text { pengembangan produk baru } \\
\text { 5. Bank memanfaatkan WGPS } \\
\text { dalam mengembangkan } \\
\text { transaksi muamalah yang } \\
\text { terintegrasi dengan bisnis }\end{array}$ \\
\hline
\end{tabular}

Economica: Jurnal Ekonomi Islam - Volume 9, Nomor 1 (2018) 
Hani Werdi Apriyanti

\begin{tabular}{|c|c|c|c|}
\hline Variabel & Definisi & Dimensi & Implikasi \\
\hline & & & $\begin{array}{l}\text { lainya (menggunakan } \\
\text { teknologi dan media) }\end{array}$ \\
\hline & & & $\begin{array}{l}\text { 6. Bank membangun kerjasama } \\
\text { dengan lembaga keuangan } \\
\text { internasional dalam upaya } \\
\text { pengembangan produk }\end{array}$ \\
\hline \multirow[t]{2}{*}{$\begin{array}{l}\text { Sharia } \\
\text { Compliance }\end{array}$} & $\begin{array}{l}\text { Pemenuhan } \\
\text { kepatuhan bank } \\
\text { syariah terhadap } \\
\text { prinsip syariah } \\
\text { dalam melakukan } \\
\text { inovasi produk }\end{array}$ & $\begin{array}{l}\text { Business } \\
\text { ethics }\end{array}$ & $\begin{array}{l}\text { 1. Bank memiliki dan } \\
\text { menggunakan Dewan } \\
\text { Pengawas Syariah (DPS) untuk } \\
\text { memastikan setiap transaksi } \\
\text { sesuai dengan ketentuan } \\
\text { syariah }\end{array}$ \\
\hline & & & $\begin{array}{l}\text { 2. Bank mengembangkan } \\
\text { kebijakan dan aturan yang } \\
\text { fleksibel dalam inovasi produk }\end{array}$ \\
\hline \multirow[t]{4}{*}{$\begin{array}{l}\text { Stabilitas } \\
\text { keuangan }\end{array}$} & $\begin{array}{l}\text { Ketersediaan } \\
\text { sumber pendanaan } \\
\text { yang dibutuhkan }\end{array}$ & Keuangan & $\begin{array}{l}\text { 1. Bank memiliki sumber } \\
\text { pendanaan untuk } \\
\text { pembiayaan yang cukup }\end{array}$ \\
\hline & $\begin{array}{l}\text { dalam proses } \\
\text { inovasi produk }\end{array}$ & & $\begin{array}{l}\text { 2. Anggaran mencakup biaya } \\
\text { penelitian dan } \\
\text { pengembangan }\end{array}$ \\
\hline & & Regulasi & $\begin{array}{l}\text { Bank berkoordinasi dengan } \\
\text { lembaga regulasi }\end{array}$ \\
\hline & & $\begin{array}{l}\text { Manajemen } \\
\text { risiko }\end{array}$ & $\begin{array}{l}\text { Bank memiliki dan meningkatkan } \\
\text { manajemen risiko }\end{array}$ \\
\hline \multirow[t]{3}{*}{$\begin{array}{l}\text { Aktivitas } \\
\text { Inovasi }\end{array}$} & $\begin{array}{l}\text { Berbagai macam } \\
\text { upaya yang } \\
\text { dlakukan oleh bank }\end{array}$ & Proses & $\begin{array}{l}\text { 1. Bank berusaha mengurangi } \\
\text { gangguan pada saat pelanggan } \\
\text { bertransaksi }\end{array}$ \\
\hline & $\begin{array}{l}\text { syariah dalam } \\
\text { proses inovasi } \\
\text { produk }\end{array}$ & & $\begin{array}{l}\text { 2. Bank melakukan peningkatan } \\
\text { kapasitas penciptaan produk } \\
\text { baru }\end{array}$ \\
\hline & & & $\begin{array}{l}\text { 3. Bank memiliki dan } \\
\text { menjalankan fungsi research }\end{array}$ \\
\hline
\end{tabular}


Model Inovasi Produk Perbankan Syariah...

\begin{tabular}{|c|c|c|c|}
\hline Variabel & Definisi & Dimensi & Implikasi \\
\hline & & \multirow{7}{*}{ Pelanggan } & $\begin{array}{l}\text { and development dalam } \\
\text { pengembangan produk }\end{array}$ \\
\hline & & & $\begin{array}{l}\text { 1. Bank menyediakan produk } \\
\text { utama/unggulan bagi } \\
\text { pelanggan }\end{array}$ \\
\hline & & & $\begin{array}{l}\text { 2. Inovasi produk selalu } \\
\text { memerhatikan aspek } \\
\text { pelanggan dan branding }\end{array}$ \\
\hline & & & $\begin{array}{l}\text { 3. Inovasi selalu } \\
\text { mempertimbangkan } \\
\text { kebutuhan pelanggan secara } \\
\text { khusus }\end{array}$ \\
\hline & & & $\begin{array}{l}\text { 4. Inovasi selalu mementingkan } \\
\text { nilai tambah bagi kepuasan } \\
\text { pelanggan }\end{array}$ \\
\hline & & & $\begin{array}{l}\text { 5. Inovasi disertai keamanan } \\
\text { produk }\end{array}$ \\
\hline & & & $\begin{array}{l}\text { 6. Produk baru mudah diperoleh } \\
\text { masyarakat }\end{array}$ \\
\hline & & ICT & $\begin{array}{l}\text { Inovasi yang dilakukan dengan } \\
\text { memanfaatkan /menerapkan ICT }\end{array}$ \\
\hline & & Marketing & $\begin{array}{l}\text { Inovasi produk meningkatkan } \\
\text { market share }\end{array}$ \\
\hline
\end{tabular}

Untuk melahirkan inovasi, bank harus didorong untuk melakukan aktivitas tambahan dalam rangka meningkatkan kualitas produk dan layanan. Dalam melakukan inovasi produk, bank syariah harus berfokus pada pelanggan dengan pemanfaatan penerapan Information and Communication Technologies (ICT) pada inovasi tersebut. Untuk menambah niai bagi pelanggan, bank syariah seharusnya mengurangi gangguan pada saat pelanggan bertransaksi. Layanan ini diberikan dengan menyediakan produk yang mudah diakses dan digunakan oleh pelanggan. Penerapan ICT pada

Economica: Jurnal Ekonomi Islam - Volume 9, Nomor 1 (2018) 
Hani Werdi Apriyanti

produk yang diberikan kepada pelanggan merupakan pemenuhan atas harapan masyarakat akan kemudahan dalam bertransaksi.

\section{Simpulan}

Inovasi produk merupakan salah satu strategi kunci dalam pengembangan perbankan syariah. Dengan pengembangan produk baru melalui proses peningkatan jaringan (WGPS), pemenuhan ketentuan syariah, pencapaian stabilitas keuangan, serta perbaikan dalam aktivitas inovasi produk, bank syariah akan mampu menarik minat masyarakat, dan memperoleh customer based baru.

Perbankan syariah harus meningkatkan kerjasama dengan berbagai pihak, terutama 0JK dalam memastikan bahwa masyarakat mengenal produk baru (literasi) dan menggunakan produk baru, dan jaringan lainya dalam WGPS. Pengawalan ini seharusnya dilakukan oleh OJK baik dalam kerangka perlindungan konsumen, maupun peningkatan literasi terhadap produkproduk perbankan syariah. Fungsi yang seharusnya terus dijalankan adalah dengan melakukan edukasi, pelayanan informasi, serta perbaikan pelayanan pengaduan dan fasilitas lainya bagi konsumen.

Untuk mendukung inovasi produk yang berkelanjutan, maka inovasi produk harus disertai dengan budaya pemasaran yang bagus melalui berbagai saluran yang ada oleh berbagai pihak, baik pemerintah, masyarakat, akademisi, dan pihak lain yang memiliki kepedulian dalam perkembangan industri perbankan syariah. Salah satu agenda yang seharusnya menjadi agenda bersama dalam WGPS perbankan syariah adalah diskusi dan workshop penguatan inovasi produk perbankan syariah, serta sinergi dalam produk bersama bank syariah di Indonesia. 
Model Inovasi Produk Perbankan Syariah...

\section{Daftar Pustaka}

Alamsyah, Halim. 2012. "Perkembangan Dan Prospek Perbankan Syariah Indonesia: Tantangan Dalam Menyongsong MEA 2015." Ceramah Ilmiah Ikatan Ahli Ekonomi Islam (IAEI), Milad Ke-8 IAEI, 13 April 2012.

Danila, Nevi. 2014. "Inovasi Produk Syariah." Jurnal Manajemen Dan Akuntansi 3 (2). http://publishing-widyagama.ac.id/ejournal-v2/index.php/jma/ article/view/259.

Fitri, Al. 2014. "Beberapa Permasalahan Perbankan Syariah Di Indonesia." 2014. https://badilag.mahkamahagung.go.id/artikel/publikasi/artikel/ beberapa-permasalahan-perbankan-syariah-di-indonesia-oleh-al-fitri-sag-s-h-m-h-i-5-11.

Gunawan, Cakti Indra, Ahmad Mukoffi, and Adrian Junaidar Handayanto. 2017. "Model Strategi Perbankan Syariah Menghadapi Persaingan Perbankan Di Era Masyarakat Ekonomi ASEAN." Research Report 0 (0): 835-44. http://research-report.umm.ac.id/index.php/research-report/ article/view/1305.

Harahap, Ahmad Taufiq. 2017. “Tantangan Dan Peluang Lembaga Keuangan Syariah." Jurnal Bisnis Corporate.

Himatansi. 2009. "Metode Dan Pilar Inovasi Produk Bank Syariah." 2009. http://www.himatansi.org/news130-metode-dan-pilar-inovasiproduk-bank-syariah.html.

Hudaya, Riandar Fata. 2011. "Strategi Inovasi Produk PT. Bank Panin Syariah Tbk Dalam Meningkatkan Daya Saing Antar Sesama Bank Syariah Dan Konvensional." Universitas Islam Negeri Syarif Hidayatullah Jakarta.

Indriati, Henni. 2011. "Analisis Faktor-Faktor Yang Mempengaruhi Inovasi Produk Perbankan Syariah Di Indonesia." Jakarta: Universitas Indonesia.

Kian, Lia. 2016. "Syariah Compliance Untuk Pengembangan Inovasi Produk Perbankan Syariah Di Indonesia." 2016. https://www.researchgate.net/ publication/321197350_Shariah_Compliance_Untuk_Inovasi_Produk_B ank_Syariah.

M. Hafidz MS., AM. 2015. "Keterlekatan Sosial Inovasi Produk Bank Syariah Di Indonesia." Jurnal Hukum Islam 13 (2): 70-78. https://doi.org/10.28918/jhi.v13i2.486.

Economica: Jurnal Ekonomi Islam - Volume 9, Nomor 1 (2018) 
Hani Werdi Apriyanti

Masulah, Siti. 2014. "Strategi Pengembangan Perbankan Syariah Di Indonesia." Jurnal Akuntansi UNESA 2 (2).

Otoritas Jasa Keuangan. 2015a. Booklet Perbankan Indonesia 2015. 2nd ed. Jakarta: Departemen Perizinan dan Informasi Perbankan Otoritas Jasa Keuangan.

-_- 2015b. Roadmap Perbankan Syariah 2015-2019. Jakarta: Departemen Perbankan Syariah Otoritas Jasa Keuangan.

_- - 2016. Booklet Perbankan Indonesia 2016. 3rd ed. Jakarta: Departemen Perizinan dan Informasi Perbankan Otoritas Jasa Keuangan.

——_. 2017. Modul Keuangan Syariah. Jakarta: Otoritas Jasa Keuangan.

Ulum, Fahrur. 2014. "Inovasi Produk Perbankan Syariah Di Indonesia." AlQānūn 17 (1): 33-59.

Utama, Satria, and Putri Ega Handini. 2017. "Inovasi Produk Penghimpunan Dana Perbankan Syariah (Studi Kasus Tabungan Arisan BPRS Madina)." In The 5th Urecol Proceeding, 908-19. Yogyakarta: Universitas Ahmad Dahlan.

Waluyo, Agus. 2016. "Kepatuhan Bank Syariah Terhadap Fatwa Dewan Syariah Nasional Pasca Transformasi Ke Dalam Hukum Positif." INFERENSI: Jurnal Penelitian Sosial Keagamaan 10 (2): 517-38. https://doi.org/10.18326/infsl3.v10i2.517-538. 